Jack Windsor Lewis*

UDK 811.111'374.2(091):81'355

University of Leeds

DOI: 10.4312/linguistica.57.1.343-356

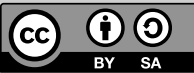

Inger M. Mees ${ }^{* *}$

Copenhagen Business School

\title{
A BRIEF HISTORICAL OVERVIEW OF PRONUNCIATIONS OF ENGLISH IN DICTIONARIES
}

\section{INTRODUCTION}

In this paper we trace dictionaries mainly of British English from their beginnings, drawing especial attention to some significant neglected or underrated writers. We examine the different ways of representing pronunciation, starting with the earliest works, which indicated pronunciation by means of conventional spelling supplemented with various diacritical signs or marks, and moving on to dictionaries where this was replaced by various systems of phonetic notation, in particular the International Phonetic Alphabet. Dictionaries produced in the USA are also briefly considered. In the twentieth century the pace of development increased, with dictionaries showing British and American usages side by side; in the twenty-first century a further development has been the introduction of audio recordings.

\section{BEFORE THE EIGHTEENTH CENTURY}

In the sixteenth and seventeenth centuries pronunciations were not indicated in dictionaries but a small number of scholars in different parts of Britain wrote about correlations of sounds to spellings. Most of them, as did Edmund Coote in his 1596 English SchooleMaister, compiled glossaries of 'hard' words but none amounted to a dictionary. An exception of importance was Henry Salesbury (c1560-c1632), an Oxford-educated Welshman, who published A Dictionary in Englyshe and Welshe in 1547, described in detail in Dobson (1968). The work was mentioned by Daniel Jones (1909) in Le Maittre Phonétique in response to a question on how earlier pronunciations of English were determined. Jones replied that one useful source was writers who 'compared the English sounds with those of foreign languages.' Salesbury, he said, 'transcribed the pronunciation of English words by means of Welsh spelling and wrote a ... treatise on Welsh pronunciation explaining ... the values of the Welsh letters' (Jones 1909: 122).

\section{THE EIGHTEENTH CENTURY}

\subsection{Dyche, Bailey and Dr Johnson}

Thomas Dyche, a schoolmaster from Derbyshire working in London, set about producing A New General English Dictionary (approximately 20,000 words) which featured

\footnotetext{
* jwl@yek.me.uk

**im.ibc@cbs.dk
} 
special attention to pronunciations. Dyche died in 1727 but the work was completed and published in 1735 by William Pardon.

The Londoner Nathan Bailey (1691-1742) published his successful Universal Etymological English Dictionary in 1727. In its Preface he explained that 'forasmuch as many Persons... are frequently apt to accent Words wrong' he offered to guide them by the use of marks placed immediately after the stressed vowel, as for example with $A b a^{\prime} n d o n$ and $A^{\prime} b b e y$. He was the first lexicographer to indicate with full regularity the positions of tonic stresses in all words.

It was Bailey's publishers who commissioned Dr Samuel Johnson (1709-1784) to produce his celebrated Dictionary of the English Language in 1755. He followed Bailey in using regular accentuation marks but offered little else on pronunciations. In 1884 James Murray, editor of the Oxford English Dictionary (OED), adopted such a system but with raised dots instead of vertical strokes, as at 'a.bi' for abbey. This system remained in the OED until 1989 when it was converted to the phonetic notation devised by the International Phonetic Association (see sections 5.2 and 9.1).

\subsection{Kenrick and Sheridan}

William Kenrick (c1730-1779) of Hertfordshire, in his New Dictionary of the English Language (1773), not only followed Bailey in his marking of stresses but was the first ever to supply full pronunciations for practically all his entries. He contrived to do this by placing numbers directly above ambiguous letters, explaining their values by a set of keywords.

Superscript numbers, over vowels only, were employed by the former actor Thomas Sheridan (1719-1788), father of the famous playwright Richard Brinsley Sheridan, in his much more complete two-volume General Dictionary of the English Language of 1780. He sought, its subtitle proclaimed, 'to establish a plain and permanent standard of pronunciation.' He came of an Irish family but had received his early education at Westminster School.

\subsection{John Walker}

During this period many people in Britain and Ireland sought to cultivate the style of speech of the metropolis and the royal court, in consequence becoming patrons of pronunciation lexicographers. The Londoner John Walker (1732-1807) became the supreme caterer to these people who were wishful to 'avoid provincialisms' when he published his Critical Pronouncing Dictionary and Expositor of the English Language in 1791. Using superscript numbers similar to Sheridan's, Walker included only minimal definitions but devoted maximum attention to their pronunciations. He recorded many variant pronunciations of each word and in many cases discussed the opinions on them of other 'orthoepists,' as such scholars were known. Often he quoted from such writers as Shakespeare, Spenser, Milton and Pope. He even noted down the actor David Garrick's pronunciation in his dramatic performances.

Walker annotated the traditional spellings of vowels by means of numbers placed directly over their letters. The consonants $/ \theta /$ and $/ \partial /$ were conveyed by respectively italicising and capitalising their 'th' spellings as at thin and THat. He had been well 
aware of the weak values of very many unaccented syllables but unfortunately chose to regard them as 'corruptions,' preferring to represent their vowels with unrealistic values. That regrettable decision was no doubt influenced by Dr Johnson's ill-judged dictum that '[f]or pronunciation the best general rule is, to consider those as the most elegant speakers who deviate least from the written words,' which Walker quoted in his

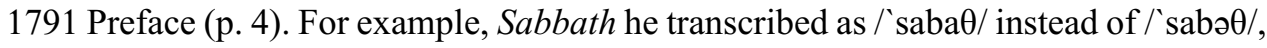
and pavement as / pervment / instead of / pervmont/.

\section{THE NINETEENTH CENTURY}

\subsection{Smart's Updating of Walker}

In 1836 a new work was published by the London grammarian Benjamin H. Smart (1787-1872). Its Preface emphasised the many changes that had occurred 'in the fifty or sixty years' since the first publication of Walker's dictionary, but this new work totally failed to eclipse the general high esteem in which Walker's was held. It compared unfavourably with Walker's detailed treatment of numerous words. In particular the decision to recommend only one of two equally current usages was ill-advised. Smart would give only one version even when admitting that between the two there was 'little in point of good usage to choose.' By contrast Walker's book had quoted as many as eight authorities' opinions at some words.

Smart's updatings included a recognition that the fashion of pronouncing words such as grass and plant with the new long /a/ instead of the older short /a/ was by now completely 'unaffected.' Instead of superscript numerals he revived the earlier tradition of using macrons and breves, though using a complex set of symbols, as, e.g. at hamadryad [hăm"- $\hat{a}$-drī' $\breve{a}$ ] . A much better system of this type was adopted in 1911 by H. W. and F. G. Fowler for their new Concise Oxford Dictionary.

\subsection{Beniowski}

An especially interesting independent set of views on British pronunciation was purveyed in the middle of the nineteenth century by Polish-born 'Major' Beniowski (c1800-1867). In the preface to his 1845 Anti-Absurd Dictionary (pp. 80-83) he offered as credentials that he had come to Britain in 1836 and 'spent seven years of a studious residence in London.'

As a speaker of a relatively rationally spelt language, he was shocked by the many irrationalities in English spelling, which he found 'absurd.' He based his Anti-Absurd Dictionary on his observations of the speech of the educated Londoners he had lived among. His transcriptions provided independent evidence of many changes from the usages of Walker's day.

\subsection{Prys}

Robert Ioan Prys's 1857 English and Welsh Pronouncing Dictionary was similar to Salesbury's Dictionary in Englyshe and Welshe (section 2) in that it used a foreign language to represent the pronunciation. Prys was from north Wales, which in the nineteenth 
century was almost entirely Welsh-speaking. A Welsh monoglot until adulthood, he had received virtually no formal education, but nevertheless managed to learn English without the help of a teacher. A major obstacle in achieving this aim was mastering the pronunciation of English, and having found a way of dealing with this problem himself, he felt he could assist others by publishing his dictionary with a transcription system based on the orthography of Welsh. It became one of the earliest dictionaries directed at non-native English users. It is notable that long before the phoneme concept had been developed, Prys appears to have been applying a largely phonemic transcription system; see Collins and Mees (1991) for a discussion of Prys's transcription scheme and Collins and Mees (2007) for a facsimile reproduction of extracts of the second 1888 edition of the dictionary as well as a translation of Prys's Welsh introduction.

\section{NINETEENTH-CENTURY DEVELOPMENTS}

\subsection{Alexander Ellis}

The scholar who did most to establish scientific phonetics in nineteenth-century Britain was the polymath Alexander John Ellis (1814-1890). His work was even recognised in the USA by the American Phonetic Council, by which he was invited to contribute to their major new American Phonetic Dictionary of the English Language (APDEL), produced by Daniel Smalley to a design by Nathaniel Storrs (Smalley 1855). Ellis furnished it with a lengthy General Introduction. APDEL anticipated the principles of the International Phonetic Association (see section 5.2) in its restricted use of diacritics, using a single symbol for each simple sound. It was fully qualified to be entitled a 'phonetic' dictionary: not only were its headwords all supplied with phonetic transcriptions but even its definitions were given in phonetic script!

\subsection{Early Influence of the IPA}

The International Phonetic Association was inaugurated in 1886 in Paris by Paul Passy (1859-1940). The Association's International Phonetic Alphabet (IPA), proposed by the great Danish linguistic scholar Otto Jespersen (1860-1943), had, after two years of planning, been finally established in 1888 .

The very first full record of English pronunciations using symbols differing only marginally from the IPA alphabet was produced by Jespersen as a major contribution to the large two-volume Dictionary of the English and Dano-Norwegian Languages (1902-1907) edited by his fellow Dane John Brynildsen. Jespersen took great pride in giving authentic representations of the vowel and consonant reductions of the natural speech of 'even the most educated speakers' (Juul et al. 1995: 115).

\subsection{George Hempl}

One of the International Phonetic Association's most enthusiastic early adherents, the American George Hempl, had been at work at much the same time, contributing to the two-volume New International French-English and English-French Dictionary, the first edition of which was dated 1903. Its editor Robert Morris Pierce listed Hempl as 
its 'Editorial Critic of English Pronunciations.' Like Jespersen, Hempl also regularly provided realistic accounts of the vowels of weak syllables. At but and to, besides /bst/ and $/ \mathrm{tu} /$, we also find /bət/ and /ta/. At because even the forms $/ \mathrm{b} ə \mathrm{k}$ ' $\mathrm{z} /$ and $/ \mathrm{kəz} /$ were included. Although with almost no recognition of the fact, this dictionary was the very first ever to use the IPA for representations of American pronunciations.

\subsection{Jon Arvid Afzelius}

In 1909 the Swede Jon Arvid Afzelius (1856-1918) published an enterprising single volume of 472 double-column pages entitled A Concise Pronouncing Dictionary of Modern English, which, though it clearly catered for a need, strangely failed to make any notable impact (Collins/Mees 2009). His transcriptions, which were remarkably accurate, were phonemic in nature although he did not employ the term 'phoneme' since the concept was at the time unknown outside Russia and eastern Europe. In a short review Daniel Jones (1910: 157) describes the book as 'a praiseworthy attempt to carry out a work of extreme difficulty,' but finds it regrettable that 'the author has not adopted the transcription of the Phonetic Association.' Afzelius observed (1909: i) that the system he had adopted was 'a slightly modified form of the phonetic notation first employed by Henry Sweet in his Primer of Spoken English [1890],' i.e. Sweet's 'Broad Romic.' Sweet was the IPA's first president and his Romic had in fact largely been the basis of the International Phonetic Alphabet.

\section{JONES AND PALMER}

\subsection{Daniel Jones (1881-1967)}

Born and bred a Londoner and a son of a leading London barrister, Daniel Jones undertook from the year 1900 intensive studies in phonetics in Germany and France. In January 1907, he gave the first of a series of lectures at University College London which were to lead to his founding of its Department of Phonetics.

\subsection{Jones's First Pronunciation Dictionary}

In 1913 Jones published a Phonetic Dictionary of the English Language jointly with Herman Michaelis, a German headmaster of a 'Mittelschule' near Wiesbaden. Its headwords were not in traditional English spelling but in an alphabetic sequence of IPA symbols. This had been adopted so that a 'person hearing a word for the first time ... may ascertain [its] current spelling' (p. vii). Large numbers of 'phonetic readers' were coming into use at this time so that, theoretically at least, the dictionary catered to a new need. The practical value of the volume was in fact seriously hampered by the unfamiliar arrangement of its entries.

\subsection{The EPD: A True Milestone}

This first lexicographical venture seems to have encouraged Jones to embark upon the writing of his English Pronouncing Dictionary. This much admired account of British 
speech, published in 1917, became an instant and lasting success. A hundred years after its first appearance it is still a classic work of reference though it has now been extensively revised (see sections 8.3 and 8.5 ). The most widespread and enthusiastic reception of his work came from the ever-expanding worldwide audience of users of English as a further language.

\subsection{The Influence of Palmer}

After Jones, the most outstanding British figure in phonetics and language learning in the earlier twentieth century was Harold Palmer (1877-1949). Despite his lack of formal qualifications, he was employed by Daniel Jones to lecture in his Department of Phonetics in 1915. Palmer stayed with Jones until 1922 when he accepted an invitation to move to Tokyo to be 'linguistic adviser' to the Japanese government.

\subsection{English Pronunciation 'with American Variants'}

In 1926, Palmer issued, with the help of the American J. Victor Martin and F. G. Blandford, a Dictionary of English Pronunciation with American Variants (DEPAV). It acknowledged the influence of G. P. Krapp and J. S. Kenyon and 'the evidence afforded by Hempl's dictionary' (1926: vi). Although the idea was promising, the completed book contained serious design flaws. After almost fifty pages of discursive introductory matter, the main text was arranged in columns headed 'Traditional Spelling,' 'Received Pronunciation' and 'American Variants.' That third column was very often sparsely filled when not actually blank. The phonetic notation was unfortunately complicated by using, besides a normal i, both a dotless [1] and an iota [1] so that, e.g. misleading appeared as ['mıs'lirdin]. The words included were often ill-judged, even wastefully giving in full all regular noun plurals, -ing-participles, and -ly forms of adjectives.

\section{AN ADVANCED LEARNER'S DICTIONARY (ALD)}

\subsection{The ALD Precursor}

A much more successful achievement of Palmer's was his very original 300-page book A Grammar of English Words (1938). As stated in its subtitle, the publication contained 'one thousand English words and their pronunciations, together with information concerning the several meanings of each word, its inflections and derivatives, and the collocations into which it enters.' The unprecedented recognition of the need for pronunciation information beyond the single-word level foreshadowed the development of the important new genre to become known as 'advanced learner's dictionaries.'

\subsection{The First ALD}

The very first of these, entitled Idiomatic and Syntactic English Dictionary, was compiled in Japan and published in 1942 from the Institute Palmer had founded by his successor A. S. Hornby, aided by two researchers, E. Gatenby and H. Wakefield. This edition was reprinted 'photographically' in 1948 by OUP as A Learner's Dictionary of Current English and re-issued in 1952 with Advanced added to its title. 


\section{PHONETIC TRANSCRIPTIONS}

\subsection{American Pronunciations Added}

The third edition of the Oxford Advanced Learner's Dictionary of Current English (OALD, Hornby et al. 1974) became a landmark publication by being the first major EFL dictionary to supply both American and British phonetic transcriptions for every one of its 100,000 entries. After this, practically all other British EFL-directed dictionaries soon became similarly equipped.

\subsection{British and American Pronunciations}

Almost half a century after the Palmer-Martin DEPAV, a new work was published by OUP with the same purpose: A Concise Pronouncing Dictionary of British and American English (CPDBAE) by J. Windsor Lewis (1972). With half the number of pages of the previous work, yet more than two-and-a-half times as many headwords, it made use of the several vowel symbols newly familiar from A. C. Gimson's Introduction to the Pronunciation of English (1962), the instantly accepted new standard description of British pronunciation, though without the length marks employed in Gimson's work (see 8.3 below). Corresponding to the established expression 'General American' for its US pronunciations, CPDBAE introduced the new term 'General British' (abbreviation 'GB') for the variety of UK accent it represented.

\subsection{A Very Influential Set of Symbols}

When Gimson revised the Jones EPD for its 1977 fourteenth edition, he represented the kit, lot, and foot vowels with the symbols /I, $\mathrm{p}, \mathrm{U} /$, replacing Jones's vowel symbols /i, $\mathrm{o}, \mathrm{u} /$, which only remained in the EPD to signify the vowel phonemes of fleece, thought and goose /i:, o:, u:/. At the same time he changed the symbol for the nurse vowel from $/ \curvearrowright: /$ to $/ 3: /$. Although, strictly speaking, length marks were no longer essential because the phonemes all had symbols that were differentiated from each other without them, he decided to retain them for the sake of clarity and continuity. His revised transcription was immediately welcomed by the leading publishers, resulting in an unprecedented uniformity of British practice.

\subsection{The Longman Pronunciation Dictionary}

In 1990 the Longman Pronunciation Dictionary (LPD), compiled by J. C. Wells (b.1939), was the first major pronunciation dictionary to provide full British and American transcriptions for all its entries. This admirable work unfortunately missed the chance to replace the outdated term 'RP' with something more suitable. It included the redundant vowel length marks though, following existing Longman house style, they were withdrawn from endings of words like happy, where the suggestion of length in such weak syllables looked particularly inappropriate. This departure from phonemic principles had appeared earlier in the Longman Dictionary of Contemporary English (Editor-in-chief Paul Procter, Pronunciation Editor Gordon Walsh, 1978), the earliest of the many emulations of the immensely popular OALD. 


\subsection{The Cambridge English Pronouncing Dictionary}

In 1997 the fifteenth edition of the Jones-Gimson EPD, newly extensively revised by Professor Peter Roach of Reading University with the collaboration of Jane Setter, at last also incorporated American pronunciations. These, supplied by the American phonetician James Hartman, were referred to as 'similar to what has been termed General American' (p. v). For the British content it proclaimed 'the time has come to abandon the archaic name Received Pronunciation.' The chosen replacement was the still unsatisfactory 'BBC English' (1997: v): since the 1960s the BBC had no longer been employing only GB speakers. Relatively trivial differences of transcription distinguished this revised EPD, now renamed Cambridge English Pronouncing Dictionary (CEPD), from the LPD. Certain complications of the transcriptions of both works have not been entirely welcome, including indications of syllabification and potential linking r's. The legibility of both also suffers from some uncomfortably condensed transcriptions. Even so both dictionaries are major achievements, especially the LPD with its valuable information on the original-language pronunciations of very many loanwords.

\subsection{Sound Provided}

A major development at the 2003 sixteenth edition of the EPD was the provision of an associated compact disc with audio recordings for all its British entries. American pronunciations for all entries followed in the 2006 seventeenth edition. The LPD followed suit at its 2008 third edition.

\section{THE OXFORD ENGLISH DICTIONARY}

\subsection{A Uniquely Comprehensive English Dictionary}

A few years before the IPA alphabet's launch in 1888, the publication had begun in 1884, by the Philological Society of London, of an English dictionary of unprecedented comprehensiveness entitled initially New English Dictionary on Historical Principles (NED), soon becoming known simply as the Oxford English Dictionary (OED). Its founding editor James Murray, being an enthusiastic phonetician, took the representation of pronunciations very seriously. Unfortunately, the system he devised was of such complexity that very few readers were fully able to interpret all its 65 symbols for vowels and 43 for consonants. The OED's first edition was not completed until 1933. By then many of its pronunciations had become out of date. For the 1989 second edition, its co-editors J. A. Simpson and E. S. C. Weiner had arranged that '[e]ssentially, a straightforward literal translation from the Murray system to IPA was attempted' (Introduction, p. xix).

\subsection{New-style Pronunciations Again}

When the OED began to incorporate American pronunciations, it was announced that '[e]ach pronunciation in the revised text is given in the International Phonetic Alphabet (IPA), according to a revised model of Received Pronunciation devised by Dr Clive 
Upton of the University of Leeds,' and similarly US pronunciations were based on 'a model devised by Professor William Kretzschmar of the University of Georgia' (Preface). The 'model' of RP involved a contradiction of the key feature of OED's own definition of $\mathrm{RP}$ as the 'most regionally neutral form of spoken British English' in that it incorporated certain undeniably regional features, for example words like bath with the trap vowel.

\subsection{Transcription Contrasts}

For a dictionary representing British and American usages side by side one might have hoped that the transcribers would have provided a conveniently maximally 'trans-Atlantic' common set of symbolisations. If they had done so, they would have avoided innumerable entries giving, e.g. the pronunciation of meat as 'Brit. /mit/ U.S. /mit/,' where, rather than phonetic contrasts, only tribal preferences are displayed. The British 'model' could easily have discarded its redundant length colons, a legacy of EFL didactics. It could have given up /əu/ in favour of /ov/. The American choice of /aI/ to represent the price diphthong would have made much more sense than $/ \Lambda \mathrm{I} /$. Preferring the use of $/ \mathrm{N} /$ for the cup vowel in the American entries, as very satisfactorily employed in the USA by Kenyon and Knott in their highly respected 1944 Pronouncing Dictionary of American English (section 10.4), would have constituted a welcome harmony. Items like 'Brit. /'beisbo:l/, U.S. /'beis,bol/' for baseball show two meaningless contrasts. One is the British redundant length mark and the other the American redundant secondary stress mark, which is superfluous because the notation $/ \mathrm{o} /$ makes it clear that the vowel in the latter syllable is not weak. Other types of unsuitably contrast-suggesting transcriptions are Brit. /'əuvl/, U.S. /'ouv(ə)1/; Brit. /'dzi:nıəs/, U.S. /'dzinjəs/; Brit. /(,)ri''ju:nıən/, U.S. /ri'junjən/ for oval, genius and reunion.

The 'barred' symbols $[\mathrm{f}]$ and $[\vartheta]$ were adopted to indicate free variation between /I/ or $/ \mathrm{v} /$ and $/ \mathrm{\partial} /$. However, some pronunciations, e.g. /ppsibl/ for possible, are either very old-fashioned or noticeably regional.

In one respect harmony did occur: the convenient Merriam-Webster-style dual stress indication, with primary and secondary marks together $\left[\begin{array}{l}1 \\ 1\end{array}\right]$ before syllables which can occur with either tonic or secondary stress, was happily adopted for 'Brit.' as well as 'U.S.' entries.

\subsection{Sound for the OED}

From 2015 the OED3 online became, extensively but not yet fully, equipped with spoken audio for at least one of the British and one of the American pronunciations for each entry. These additions, though they may not always be managed ideally by the speakers employed to produce them, undoubtedly constitute a valuable new development.

\subsection{The Oxford Dictionary of Pronunciation}

An OED offspring, the Oxford Dictionary of Pronunciation for Current English (ODPCE) appeared in 2001, with leading editors Clive Upton and William A. Kretzschmar Junior. These authors' 'models' had also been adopted for OED3, which said 
' $[t]$ he pronunciations given are those in use among educated urban speakers of standard English in Britain and the United States ... avoiding strongly regionally or socially marked forms.' Nevertheless, ODPCE, like OED3, admitted numerous obviously regional (though educated) variants. Such inclusions are perfectly acceptable, indeed valuable. They were included in LPD as 'BrE non-RP,' but very sparse in CEPD. Oddly enough, they were omitted (without comment) in 2017 when, after a sixteen-year absence, ODPCE re-emerged enlarged as the Routledge DPCE.

\section{THE MOST IMPORTANT AMERICAN DICTIONARIES}

\subsection{Noah Webster}

The earliest significant American lexicographer Noah Webster (1758-1843) was at great pains to take account of the works of numerous British orthoepists, devoting six tightly packed pages ( $\mathrm{x}-\mathrm{xvi})$ to their works in the Preface to his Compendious Dictionary of the English Language of 1806, although he had earlier (Webster 1789: 124) condemned their prescriptions as based on 'false principles.' Although his own principles were not completely scientific either, he was, of course, right that various British writers of the period had set themselves up as arbiters of correct usage on at times rather dubious grounds, as we saw with the transcription of weak syllables as if they were strong.

\subsection{The Finest Webster Edition}

In the twentieth century, pronunciations in Merriam-Webster's dictionaries were notably from 1946 to his retirement in 1973 chiefly in the expert hands of Edward Artin (1905-1974). The two hefty volumes of the still uneclipsed Third New International Dictionary of 1961 (Editor-in-chief Philip Babcock Gove) contained a very thorough 'Guide to Pronunciation' covering fifteen large triple-columned pages. Its transcriptions used a complicated 'diacritic-respelling' system in which phonetic values were indicated by added superscript diacritics such as macrons and diaereses to letters of traditional English spelling, e.g. $\bar{a}$ as in day, ä as in pot etc. Artin expressed regret at being obliged to use this not very elegant type of notation because of not finding any 'desire among those who buy such dictionaries for the kind of alphabet that we would prefer to transcribe in' (Artin 1973: 1). This largest Webster was rich in information even to a certain extent on neglected matters such as the stress features of compound words.

\subsection{Best of Both Worlds}

James F. Bender's NBC Handbook of Pronunciation $(1943,1964)$ seems to have been the only American dictionary of moderate size which provided for all of its 'more than 20,000 entries' (p. vii) not only a 'diacritic-respelling' but also (in a separate column) 'IPA Symbols.'

\subsection{Kenyon and Knott}

John Samuel Kenyon (1874-1959) entered into co-operation with his fellow Webster editor Thomas A. Knott (1880-1945) for the compilation of their 1944 Pronouncing 
Dictionary of American English (PDAE). It took them six years to complete this difficult task, one much more exacting than Daniel Jones had faced in producing his EPD. Jones had chosen only to consider a relatively narrowly definable single British accent of which he had the advantage of being himself a native speaker. Kenyon and Knott undertook to represent in their PDAE 'several different types of speech used by large bodies of educated and cultivated Americans in widely separated areas' (p. v). Astonishingly, PDAE has never been in any respect revised since a mere four-page Addenda of 1949 (pp. liii-lvi). Inevitably its wordlist has not kept up with the times but it has remained a highly regarded authority. Kenyon and Knott employed the IPA throughout their dictionary.

\section{PRONUNCIATION IN DICTIONARIES TO COME}

In the not very distant future it is probable that paper dictionaries will be found only in libraries if not only in museums. The OUP has already announced that its twentyvolume book form will not be revised as such. Professor Jane Setter in a blog posting of the 18th of April 2017 remarked regarding CEPD that ' $[\mathrm{t}]$ here are no current plans to produce any further print editions of the dictionary; ... and CUP have told us that the way forward...is electronic editions only.'

Spoken audio reference materials will no doubt increasingly extend beyond the provision of pronunciations of individual words. In addition, the present practice of providing a single pronunciation for each word by a single speaker may well be extended by offering for each of a word's pronunciations not only choices of transcribed variants but choices of voices and accents, going beyond General British and General American to Australian, Canadian, Caribbean, Hong Kong, Irish, New Zealand, Philippine, Scottish, Singapore and South African. Such a range of varieties has already slowly begun to feature in the OED.

Archaic and obsolete words now not even accorded transcriptions by the OED may well in future be made available in reconstructions accompanied with audio versions. Already all of the $60 \%$ of the 40,000 individual words occurring in the works of Shakespeare that were differently pronounced in his day have now been recorded with reconstructed pronunciations of his era, spoken by David Crystal in illustration of his 2016 Oxford Dictionary of Original Shakespearean Pronunciation. It seems very possible that such recordings will in the future become incorporated into OED entries.

\section{References}

AFZELIUS, Jon Arvid (1909) A Concise Pronouncing Dictionary of Modern English. Stockholm: Norstedt. Reproduced in a facsimile edition: Beverley Collins/Inger M. Mees/Paul Carley (eds) (2013) English Phonetics: Twentieth Century Developments. Vol. 1. London: Routledge.

ARTIN, Edward (1973) "Dictionary treatment of pronunciation: General." Annals of the New York Academy of Sciences 211, 125-128. http://dx.doi. org/10.1111/j.1749-6632.1973.tb49482 
BAILEY, Nathaniel (1727) An Universal Etymological English Dictionary. London: Bell et al.

BENDER, James F. ( ${ }^{3} 1964$ [1943]) NBC Handbook of Pronunciation. New York: Thomas Y. Crowell.

BENIOWSKI, Major (1845) Anti-absurd or Phrenotypic English Pronouncing and Orthographical Dictionary. London: published by the author.

BRYNILDSEN, John (1902-07) Engelsk-Dansk-Norsk Ordbog [English-Danish-Norwegian dictionary]. (English pronunciations by Otto Jespersen.) Copenhagen: Gyldendalske Boghandel, Nordisk Forlag.

COLLINS, Beverley/Inger M. MEES (1991) "English through Welsh Ears: The 1857 Pronunciation Dictionary of Robert Ioan Prys." In: Ingrid Tieken-Boon van Ostade/John Frankis (eds), Language Use and Description. Amsterdam: Rodopi, 75-90.

COLLINS, Beverley/Inger M. MEES (eds) (2007) Phonetics of English in the Nineteenth Century. vol. 1. London: Routledge.

COLLINS, Beverley/Inger M. MEES (2009) "The Hundredth Anniversary of the First Modern English Pronunciation Dictionary." In: Michael Ashby/John Maidment (eds), Proceedings of the Phonetics Teaching and Learning Conference, Aug 6-8, 2009, University College London. London: Phonetics Teaching and Learning Conference, 35-38.

COOTE, Edmund (1596) The English Schoole-maister. London: R. Jackson \& R. Dexter.

CRYSTAL, David (2016) The Oxford Dictionary of Original Shakespearean Pronunciation. Oxford: Oxford University Press.

DOBSON, Eric J. ( $\left.{ }^{2} 1968\right)$ English Pronunciation 1500-1700. Oxford: Clarendon Press. DYCHE, Thomas (1735) A New General English Dictionary. London: C. \& R. Ware. FOWLER, Henry W./Francis G. FOWLER (eds) (1911) The Concise Oxford Dictionary. Oxford: Clarendon Press.

GIMSON, Alfred Charles (1962) An Introduction to the Pronunciation of English. London: Arnold.

GOVE, Philip Babcock (ed.) (1961) Webster's Third New International Dictionary. (Pronunciation editor: Edward Artin). Springfield, MA: G. \& C. Merriam.

HEMPL, George: See Pierce (1903).

HORNBY, Albert Sydney/Anthony P. COWIE/Jack WINDSOR LEWIS ( $\left.{ }^{3} 1974\right) O x-$ ford Advanced Learner's Dictionary of Current English. London: Oxford University Press.

HORNBY, Albert Sydney/Edward V. GATENBY/Harold WAKEFIELD (1942) Idiomatic and Syntactic English Dictionary. Tokyo: Institute for Research in Language Teaching. [This original edition was reissued in 1948 as A Learner's Dictionary of Current English. London: Oxford University Press. Its title in 1952 was changed to The Advanced Learner's Dictionary of Current English.]

JOHNSON, Dr Samuel (1755) A Dictionary of the English Language. London: Strahan. JONES, Daniel (1909) "The pronunciation of Early English." Le Maître Phonétique 2/24, 119-123.

JONES, Daniel (1910) “Review of Afzelius (1909).” Le Maître Phonétique 2/25, 157. 
JONES, Daniel (1917) An English Pronouncing Dictionary. London: Dent. [14th edn edited by A. C. Gimson, 1977. From 15th edition as Cambridge English Pronouncing Dictionary, edited by Roach et al. 1997. Cambridge University Press.]

JUUL, Arne/ Hans F. NIELSEN/Jørgen Erik NIELSEN (eds) (1995) A Linguist's Life: an English Translation of Otto Jespersen's 1938 Autobiography. Odense: Odense University Press.

KENRICK, William (1773) A New Dictionary of the English Language. London: John \& Francis Rivington et al.

KENYON, John S./Thomas A. KNOTT (1944) A Pronouncing Dictionary of American English (PDAE). Springfield, MA: G. \& C. Merriam.

MICHAELIS, Hermann/Daniel JONES (1913) A Phonetic Dictionary of the English Language. Berlin: Carl Meyer. [Reproduced in a facsimile edition: Beverley Collins/ Inger M. Mees (2003) Daniel Jones: Selected works. Vol. 2. London: Routledge.]

MURRAY, James A. H. (ed.) (1884) A New English Dictionary on Historical Principles. Oxford: Clarendon Press.

PALMER, Harold E. (1938) A Grammar of English Words. London: Longmans.

PALMER, Harold E./J. Victor MARTIN/F. G. BLANDFORD (1926) A Dictionary of English Pronunciation with American Variants (DEPAV). Cambridge: Heffer.

PIERCE, Robert Morris (1903) New International French-English and English-French Dictionary. New York: Hinds and Noble.

PROCTER, Paul (ed.) (1978) Longman Dictionary of Contemporary English. Harlow, UK: Longman.

PRYS, Robert Ioan (1857) Geiriadur Cynaniadol Saesneg Chymraeg [An English \& Welsh pronouncing dictionary], 2nd edn. 1888. [Reproduced in a facsimile edition: Beverley Collins/Inger M. Mees (2007) Phonetics of English in the Nineteenth Century. Vol. 1. London: Routledge.]

ROACH, Peter/James HARTMAN/Jane SETTER (eds) (1997) Cambridge English Pronouncing Dictionary. [15th edn of the Daniel Jones EPD; 16th edn 2003; 17th edn 2006.] Cambridge: Cambridge University Press.

SALESBURY, Henry (1547) A Dictionary in Englyshe and Welshe. London: John Waley.

SHERIDAN, Thomas (1780) A General Dictionary of the English Language. London:

J. Dodsley et al.

SIMPSON, John A./Edmund S. C. WEINER ( ${ }^{21989)}$ Oxford English Dictionary. Oxford University Press.

SMALLEY, Daniel S (1855) American Phonetic Dictionary of the English Language. Cincinnati: Longley Brothers.

SMART, Benjamin H. (1836) Walker Remodelled: A New Critical Pronouncing Dictionary of the English Language. London: T. Cadell.

SWEET, Henry (1890) A Primer of Spoken English. Oxford: Clarendon Press.

UPTON, Clive/William A. KRETZSCHMAR/Rafal KONOPKA (2001) Oxford Dictionary of Pronunciation for Current English (ODPCE). Oxford: Oxford University Press. [2nd edn. 2017, revised by Upton and Kretzschmar, The Routledge Dictionary of Pronunciation for Current English. Abingdon: Routledge.] 
WALKER, John (1791) A Critical Pronouncing Dictionary and Expositor of the English Language. London: G. \& J. Robinson.

WEBSTER, Noah (1789) Dissertations on the English Language. Printed for the author by I. Thomas \& Co.

WEBSTER, Noah (1806) A Compendious Dictionary of the English Language. Hartford/New Haven: Hudson \& Goodwin.

WELLS, John C. ( $\left.{ }^{3} 1990\right)$. Longman Pronunciation Dictionary. Harlow: Longman. [2008, Harlow: Pearson Education.]

WINDSOR LEWIS, J. (1972) A Concise Pronouncing Dictionary of British and American English (CPDBAE). London: Oxford University Press.

\section{Abstract \\ A BRIEF HISTORICAL OVERVIEW OF PRONUNCIATIONS OF ENGLISH IN DICTIONARIES}

The evolution of pronunciations in mainly British English dictionaries is traced from their beginnings, with accounts of certain neglected figures in the field. In the paper we discuss how representations of pronunciations have developed from being indicated by means of conventional spelling with the addition of marks and numbers to more sophisticated systems of phonetic notation. A significant feature of the twentyfirst century is the addition of spoken pronunciations of the items.

Keywords: pronunciation lexicography, pronunciations of British English, phonetic notation, International Phonetic Alphabet, history of pronunciation dictionaries

\section{Povzetek \\ KRATEK ZGODOVINSKI PREGLED ANGLEŠKE IZGOVARJAVE V SLOVARJIH}

Prispevek sledi razvoju izgovarjave $\mathrm{v}$ slovarjih britanske angleščine od samega začetka, pri čemer opiše nekatere pogosto spregledane posameznike, ki so delovali na tem področju. Obravnava tudi razvoj zapisovanja izgovarjave, ki je sprva uporabljal navadno pisavo z nekaterimi dodatnimi znaki in številkami, do bolj izpopolnjenih sistemov fonetičnega zapisa. Pomemben doprinos slovarjev 21. stoletja je dodajanje posnete izgovarjave besed.

Ključne besede: leksikografija izgovarjave, izgovarjava britanske angleščine, fonetični zapis, mednarodna fonetična abeceda, zgodovina slovarjev izgovarjave 